\title{
Effect of Different Levels of Potassium Fertilizer on Yield and Fruit Quality of Old Trees of "Balady" Orange \\ A: Effect of Different Levels of Potassium Fertilizer on Some Physical Prop- erties and Yield Parameters of "Balady" Orange
}

\section{El-Mahdy, T.K.; Maha M. Abdel-Salam; R.A. Ibrahim Manal A. Mahmoud}

Department of Pomology, Faculty of Agriculture, Assiut University, Assiut, Egypt *Email: rashad.ibrahem@aun.edu.eg

Received on: $16 / 1 / 2019$

Accepted for publication on: 24/2/2019

\section{Abstract}

This experiment was carried out during two successive seasons 2015 and 2016 on the orchard of Faculty of Agriculture, Assiut University. This study aimed to investigate the effect of potassium sulfate $(\mathrm{K})$ fertilizer at different rates, application times and method of application on yield parameters and fruit properties of old trees of Balady orange cv. The obtained results showed that all $\mathrm{K}$ treatments significantly increased the fruit set (\%), number of fruits/tree, total yield/tree $(\mathrm{kg})$, fruit weight $(\mathrm{g})$, fruit height and diameter $(\mathrm{cm})$ as compared with control (untreated trees) during both experimental seasons. Moreover, the three times applications and foliar sprays were more effective than twice applications and ground adding of potassium sulfate $(\mathrm{K})$, respectively.

The lowest values of these parameters, were recorded in control (untreated trees), while the foliar application of $666 \mathrm{~g}+90 \mathrm{mlsprays} /$ tree of potassium sulfate $(\mathrm{K})$ three times gave the highest values during both tested seasons.

Keyword: Balady orange, potassium sulfate, yield parameters.

Introduction

Citrus are evergreen fruit trees that belong to family rutaceae which contains three genera (Citrus - Kumquates and Trifoliate orange). Citrus is the most important of them which includes orange, mandarins, lemon, grapefruit and sour lime and occupies the second rank of fruit world production.Although orange occupies the greatest planted area among all citrus grown fruit area in Egypt, the exportation of fresh orange fruits to the foreign markets are still limited compared with the produced quantity. Citrus are considered an important fruits in many parts of the world because it has a high nutritional value of vitamins, essential oils, minerals, sugars and salts. Orange is considered as a main source of antioxidants like vitamin $\mathrm{C}$, phenolic compounds and carotenoids, so it has important functions in resistance against many human illnesses (Del-Caro et al., 2004; Dhuique et al., 2005 and $\mathrm{Wu}$ et al., 2007). Fruits are rich in vitamin $C$ and other components such as phenols and flavonoids which are very beneficial for human health (Hand et al., 2005).

Potassium was the only element which is low or deficient in different Egyptian soils and suggesting its cossection in Balady mandarin by soil application of either $\mathrm{K}_{2} \mathrm{SO}_{4}$ or $\mathrm{KNO}_{3}$ or sprays of both. The selection of the appropriate method depends in large extent on the $\mathrm{CaCO}_{3}$ content of the soil. It was also reported that soil ap- 
plication of $\mathrm{K}$ failed to raise leaf $\mathrm{K}$ content but sprays increased it (ElDarier, 1991).

Potassium is also important in formation and functioning of proteins, fats, carbohydrates and chlorophyll and in maintaining the balance of salts and water in plant cells (Achilea, 1998). Heavy citrus orchards should receive considerable amount of K, nearly at the same level as nitrogen, in order to preserve high yields of fruits with the required qualities. The relatively high acid level caused by application of $\mathrm{K}$ can be qualified, in most cases, by briefly delaying the harvest. The physiological functions of potassium and its conspicuous role in plant water relations has long been known and serve to emphasize that there should be adequate $\mathrm{K}$ contents in all plant parts (Nijjar, 1985; Hsiao and Lauchli, 1986; Davies and Albrigo, 1994; Boman, 1997; Mostafa and Saleh, 2006 and El-Tanany et al., 2011).

Therefore, $\mathrm{K}$ sprays can be an effective method to shorten the time required to uptake compared to soil application (Embleton et al., 1969). The most common methods of applying potassium to citrus are the traditional broadcasting of granular materials or by injection of liquid nutrient solutions through the irrigation system. Supplemental nutrient sprays have been shown to be effective for correcting potassium deficiencies for citrus (Calevert et al., 1972; Erner et al., 1993; Achilea, 1998 and Mostafa et al., 2005).

This investigation aimed to study the effect of foliar spray or ground application of different rates of $\mathrm{K}$ fertilizer on yield parameters and some physical fruit properties of old Balady orange trees under Assiut environmental condition.

\section{Materials and Methods}

This experiment was conducted over a period of two successive seasons 2015 and 2016 on Balady orange trees (Citrus sinensis) grown at the Experimental Orchard of Faculty of Agriculture, Assiut University, where the soil is a well-drained fertile silty loam. Thirty nine (39) old trees of Balady orange cv. About 45 years old at uniform vegetative vigour were selected for this investigation to study the effect of different methods and concentration of potassium sulfate (K-52\%) on yield parameters as well as some physical properties of its fruits.

The chosen trees received the standard agricultural practices that are used in the orchard, except for the tested treatments of $\mathrm{K}$ during the two studied seasons.

Thirteen different treatments of potassium sulfate $52 \%$ were used for the selected trees as foliar spraying or adding to the soil as follows:

1- Control. (t1)

2- Potassium sulfate $(1 \mathrm{~kg} /$ tree $)$ twice adding to soil.

3- Potassium sulfate (666 gm /tree) three times adding to soil.

4- Potassium sulfate $(135 \mathrm{ml} /$ tree $)$ twice foliar sprays.

5- Potassium sulfate $(90 \mathrm{ml} /$ tree $)$ three times foliar sprays.

6- Potassium sulfate $(500 \mathrm{~g} /$ tree to soil $+67.5 \mathrm{ml}$ spray) twice applications.

7- Potassium sulfate (333g / tree to soil $+45.0 \mathrm{ml}$ spray) three times. 
8- Potassium sulfate (2 $\mathrm{kg} /$ tree $)$ twice adding to soil.

9- Potassium sulfate $(1330 \mathrm{~g} /$ tree $)$ three times adding to soil.

10- Potassium sulfate $(270 \mathrm{ml} /$ tree $)$ twice sprays.

11- Potassium sulfate $(180 \mathrm{ml} /$ tree $)$ three times sprays.

12- Potassium sulfate $(1 \mathrm{~kg}$ to soil + $135 \mathrm{ml}$ spray) twice applications.

13- Potassium sulfate $(666 \mathrm{gm} /$ tree $+90 \mathrm{ml}$ spray) three times applications.

Some treatments of foliar spraying or adding to soil were applied twice( in the first week of each of March and June), where the other were applied three times (in the first week of each of March, June and August).

The experiment was arranged as factorial in complete randomized block design with three replications for each treatment (one tree was devoted for each replicate).

The following measurements were carried out:

\section{A- Yield parameters:}

\section{A.1- Fruit set percentage:}

Three shoots on each tree (replicate) were randomly selected and tagged to determine the percentage of fruit set as follow:

$\%$ fruitset $=\frac{\text { Av. number of fruit set } / \text { shoot }}{A v \cdot \text { number of total flowers } / \text { shoot }} \times 100$

\section{A.2- Number of fruit and yield/tree:}

At the harvest date (TSS/acidity ratio) were about 12.8 to $13.6 \%$ the number of fruits/tree were counted and the yield $(\mathrm{kg})$ per tree was determined.

\section{B- Fruit properties:}

Three uniform fruits were randomly taken at harvest date from each tree (replicate) and transported to the laboratory to determine the following fruit properties.

B-1-Average fruit weight (gm)

B-2-Fruit dimension: A varnier caliper was used to measure the fruit hight $(\mathrm{cm})$ and fruit diameter $(\mathrm{cm})$ then shape index was calculated as:

Shape index $=\frac{\text { Fruit height }(H)}{\text { Fruit diameter }(D)}$

\section{Statistical analysis:}

Data were tabulated and statistically analyzed and the differences were tested by analysis of variance (ANOVA) according to Snedecor and Cochran (1989) Means were compared using the least significant difference (LSD) values of 5\% level of the probability.

\section{Results and Discussion \\ A- Yield parameters:}

The effect of different methods and concentration of potassium sulfate $(\mathrm{K})$ application on yield parameter of Balady orange namely, fruit set percentage, number of fruits per tree and total yield $(\mathrm{kg} /$ tree $)$ are shown in Table (1). In general all applied treatments had positive effect concerning these parameters comparing with control during both tested seasons.

\section{A.1: Fruit set percentage:}

The obtained data in Table (1) showed that, all concentrations and methods of $\mathrm{K}$ applications significantly increased the percentage of fruit set as compared with control (without $\mathrm{K}$ addition) during both experimental seasons. The lowest fruit set $\%(1.33$ and $1.40 \%)$ were recorded by control, while the highest 
values (5.66 and 6.66\%) were found by $666 \mathrm{~g}+90 \mathrm{ml}$ of potassium sulfate/tree during both tested seasons, respectively. Moreover, it could be noticed that, the fruit set $\%$ was significantly increased by increasing the concentration of potassium sulfate as well as the number of addition (twice or three times) during both seasons 2015 and 2016 seasons.

\section{A.2: Number of fruits/tree:}

The obtained results in Table (1) indicated that, all $\mathrm{K}$ treatments increased the number of fruits/tree as compared with control during both investigated seasons. These results took approximately the same trend during both seasons, where the significant effect was found from T3 up to $\mathrm{T} 13$, while $\mathrm{T} 1$ in the first season and $\mathrm{T} 1, \mathrm{~T} 2$ in the second season had slight and non-significant increase comparing with the untreated trees (control). In addition, the fertilized trees with $90 \mathrm{ml}$ spray $+666 \mathrm{gm} /$ tree potassium sulfate (T13) gave the highest average number of fruits/tree (336.7 and 378 fruits/tree), while the lowest average number of fruits was recorded by control trees (77.33 and 94.6 fruits/tree) during both tested seasons, respectively. Moreover, it could be noticed that the distribution of the same rate (doses) of potassium sulfate through 3 times application was more effective than those of twice applications during both seasons.

\section{A.3: Yield/tree (kg):}

Data in table (1) show the total yield/tree of Balady orange as affected by potassium sulfate $(\mathrm{K})$ fertilization as foliar sprays or adding to the soil during 2015 and 2016 seasons.

The obtained results were positivly correlated with the number of fruits/tree and took approximately the same tendency during both tested seasons.

The total yield/tree $(\mathrm{kg})$ was significantly increased by all the applied treatments of potassium sulfate (K) comparing with untreated trees (control). The highest average yield/tree (55.32 and $61.3 \mathrm{~kg} /$ tree $)$ were obtained by application of 666 $\mathrm{g}+90 \mathrm{ml}$ of P. sulfate/tree (T13), while the lowest average of yield/tree ( 8.37 and $11.6 \mathrm{~kg}$ ) were recorded by untreated trees (T1) during both experimental seasons, respectively. Additionally, three times applications of $K$. sulfate were more effective than twice applications of the same rates (doses) of K. sulfate during both seasons.

These results took the same line of those obtained by Nijjar, 1985; Hsiao and Lauchli, (1986;) Davies and Albrigo, (1994;) Boman, (1997;) Mostafa and Saleh, (2006), and ElTanany et al., (2011). Muhammad y and Manzoor A (2010). 
Table 1. Effect of different levels and methods of fertilization by potassium sulfate (K) on yield parameters of Balady orange cv. during 2015 season.

\begin{tabular}{|l|c|c|c|c|c|c|c|c|c|c|c|c|c|c|}
\hline Treat param & T1 & T2 & T3 & T4 & T5 & T6 & T7 & T8 & T9 & T10 & T11 & T12 & T13 & LSD \\
\hline Yield tree (kg) & 8.37 & 9.34 & 12.83 & 13.53 & 14.33 & 15.87 & 21.43 & 24.06 & 25.07 & 27.71 & 37.46 & 39.58 & 55.32 & 2.69 \\
\hline Fruit number/tree & 77 & 82 & 102 & 113 & 115 & 117 & 151 & 168 & 175 & 185 & 233 & 232 & 336 & 21.9 \\
\hline Initial fruit set & 1.33 & 2.43 & 3.00 & 3.46 & 3.50 & 4.63 & 4.83 & 4.96 & 5.26 & 5.46 & 5.73 & 5.83 & 6.66 & 0.38 \\
\hline
\end{tabular}

Table 2. Effect of different levels and methods of fertilization by potassium sulfate (K) on yield parameters of Balady orange cv. during 2016 season.

\begin{tabular}{|l|c|c|c|c|c|c|c|c|c|c|c|c|c|c|}
\hline Treat param & T1 & T2 & T3 & T4 & T5 & T6 & T7 & T8 & T9 & T10 & T11 & T12 & T13 & LSD \\
\hline Yield tree (kg) & 11.6 & 12.6 & 13.5 & 17.7 & 23.5 & 26.8 & 29 & 27 & 32.3 & 36.3 & 44.9 & 50.1 & 61.3 & 2.23 \\
\hline Fruit number/tree & 94 & 98 & 104 & 134 & 742 & 193 & 206 & 190 & 224 & 248 & 298 & 312 & 378 & 22 \\
\hline Initial fruit set & 1.40 & 1.96 & 2.4 & 2.6 & 3 & 3.13 & 3.20 & 3.50 & 3.73 & 4.10 & 4.50 & 4.80 & 5.66 & .146 \\
\hline
\end{tabular}

T1: Control.

T2: Potassium sulfate (1 $\mathrm{kg}$ tree) twice adding to soil.

T3: Potassium sulfate (666gm tree) three times adding to soil.

T4: Potassium sulfate ( $135 \mathrm{ml}$ tree) twice foliar sprays.

T5: Potassium sulfate $(90 \mathrm{ml}$ tree) three times foliar sprays.

T6: Potassium sulfate $(500 \mathrm{~g}$ to soil $+67.5 \mathrm{ml}$ spray) twice applications.

T7: Potassium sulfate ( $333 \mathrm{gm}$ to soil $+45.0 \mathrm{ml}$ spray) three .

T8: Potassium sulfate (2 $\mathrm{kg} /$ tree) twice adding to soil.

T9: Potassium sulfate (1330 g/tree) three times adding to soil.

T10: Potassium sulfate $(540 \mathrm{ml} /$ tree) twice sprays.

T11: Potassium sulfate $(180 \mathrm{ml} /$ tree $)$ three times sprays.

T12: Potassium sulfate ( $1 \mathrm{~kg}$ to soil $+135 \mathrm{ml}$ spray) twice applications.

T13: Potassium sulfate $(666+90)$ three times applications. 


\section{B- Fruit properties:}

\section{B.1: Fruit weight (g):}

The response of fruit weights to $\mathrm{K}$ fertilization as spraying or ground applying during 2015 and 2016 seasons are presented in Tables $(3,4)$. It is worth to mention that fruit weight of Balady orange cv. reacted similary and took the same trend during both experimental seasons. All applied K treatments significantly increased fruit weight $(\mathrm{g})$ comparing with control during both seasons. Moreover, the thrice application of $\mathrm{K}$ fertilizer were more effective than those of twice as spraying or ground adding. The highest average values of fruit weight were found by thrice application of K-sulfate at $666 \mathrm{~g}+90 \mathrm{ml}$ rate (164.0 and $162.0 \mathrm{~g}$ ), while the lowest values were recorded by control $(108.0$ and $120.0 \mathrm{~g})$ during both tested seasons, respectively.

\section{B.2: Fruit height (H) and diameter} (D):

Data in tables $(3,4)$ show the effect of sprays or soil adding of potassium sulfate on fruit height $(\mathrm{cm})$ and fruit diameter $(\mathrm{cm})$ of Balady orange $\mathrm{cv}$. during 2015 and 2016 seasons.

It is clear to notice that both fruit properties approximately were affected similarly by all the applied treatments during both investigated seasons. All sprays or soil adding of $\mathrm{K}$ treatments at all rates significantly increased both of fruit height and diameter as compared by control during both tested seasons.

The highest values of fruit height were measured by thrice applicate of K (T13) during 2015 and 2016 seasons $(6.7$ and $6.46 \mathrm{~cm})$, respectively, while the untreated fruits (control) had the lowest height (5.70 and $5.73 \mathrm{~cm}$ ).

The response of Balady orange fruits to $\mathrm{K}$ fertilizer concerning its diameter took approximately the same trend of fruit height. T13 (666 $\mathrm{g}+90 \mathrm{ml})$ produced the highest values of fruit diameter $(6.5$ and $6.6 \mathrm{~cm})$, while the lowest values of diameter were recorded by control fruits (5.7 and $5.6 \mathrm{~cm}$ ) during both tested seasons.

\section{B.3: Fruit shape index (H/D):}

Data in Tables $(3,4)$ show the shape index of Balady orange fruits as affected by K-fertilization during 2015 and 2016 seasons. 
Table 3. Effect of different levels and methods of fertilization by potassium sulfate (K) on some physical properties of Balady orange fruits cv. during 2015 season.

\begin{tabular}{|l|c|c|c|c|c|c|c|c|c|c|c|c|c|c|}
\hline Treat param & T1 & T2 & T3 & T4 & T5 & T6 & T7 & T8 & T9 & T10 & T11 & T12 & T13 & LSD \\
\hline Fruit weight(gm) & 108 & 114 & 119 & 119 & 124 & 135 & 141 & 142 & 143 & 149 & 161 & 162 & 164 & 1.58 \\
\hline Fruit height(cm) & 5.7 & 6.1 & 6.3 & 6.3 & 6.4 & 6.4 & 6.4 & 6.5 & 6.5 & 6.6 & 6.6 & 6.6 & 6.7 & 0.151 \\
\hline Fruit diameter & 5.7 & 5.7 & 6.0 & 6.3 & 6.3 & 6.3 & 6.2 & 6.2 & 6.3 & 6.4 & 6.5 & 6.5 & 6.5 & 0.261 \\
\hline Shape index & 1 & 1.06 & 0.99 & 1.6 & 1.17 & 1.17 & 1.12 & 1.23 & 1.03 & 1.01 & 1.06 & 1.06 & 1.4 & 0.134 \\
\hline
\end{tabular}

Table 4. Effect of different levels and methods of fertilization by potassium sulfate (K) on some physical properties of Balady orange fruits cv. during 2016 season.

\begin{tabular}{|l|c|c|c|c|c|c|c|c|c|c|c|c|c|c|}
\hline Treat param & T1 & T2 & T3 & T4 & T5 & T6 & T7 & T8 & T9 & T10 & T11 & T12 & T13 & LSD \\
\hline Fruit weight & 120 & 127 & 130 & 131 & 133 & 134 & 141 & 141 & 144 & 145 & 150 & 160 & 162 & 4.90 \\
\hline Fruit height & 5.73 & 5.93 & 6 & 6.16 & 6.20 & 6.23 & 6.23 & 6.30 & 6.33 & 6.36 & 6.40 & 6.43 & 6.46 & 0.239 \\
\hline Fruit diameter & 5.6 & 5.9 & 6 & 6.1 & 6.1 & 6.2 & 6.2 & 6.2 & 6.3 & 6.3 & 6.5 & 6.6 & 6.6 & 0.24 \\
\hline Shape index & 1.18 & 1 & 1 & 1 & 1 & 0.99 & 1 & 1 & 1 & 1.1 & 0.97 & 0.97 & 0.97 & 0.117 \\
\hline
\end{tabular}

T1: Control.

T2: Potassium sulfate (1 $\mathrm{kg}$ tree) twice adding to soil.

T3: Potassium sulfate (666gm tree) three times adding to soil.

T4: Potassium sulfate (135ml tree) twice foliar sprays.

T5: Potassium sulfate (90 $\mathrm{ml}$ tree) three times foliar sprays.

T6: Potassium sulfate (500g to soil $+67.5 \mathrm{ml}$ spray) twice applications.

T7: Potassium sulfate ( $333 \mathrm{gm}$ to soil $+45.0 \mathrm{ml}$ spray) three

T8: Potassium sulfate $(2 \mathrm{~kg} /$ tree $)$ twice adding to soil.

T9: Potassium sulfate ( $1330 \mathrm{~g} /$ tree) three times adding to soil.

T10: Potassium sulfate $(540 \mathrm{ml} /$ tree $)$ twice sprays.

T11: Potassium sulfate $(180 \mathrm{ml} /$ tree $)$ three times sprays.

T12: Potassium sulfate (1 kg to soil $+135 \mathrm{ml}$ spray) twice applications.

T13: Potassium sulfate $(666+90)$ three times applications 
Generally the calculated shape index was correlated with the changes in both fruit height and diameter as affected by different rates and methods of $\mathrm{K}$ treatments during both seasons.

It could be noticed that, all Ktreatments slightly or significantly increased the shape index during the first experimental season 2015, while all treatments significantly decreased the shape index of Balady orange fruits during the second season 2016 . These obtained results could be due to the increase of fruit diameter during the second season 2016.

These results are in agreement with those found by Boman (1997), Achilea (1998), Mostafa and Saleh (2006), Ashraf et al. (2010), ElTanany et al. (2011) and Jose et al. (2011).

\section{References}

Achilea, O. (1998). Citrus and tomato quality is improved by optimized $\mathrm{K}$ nutrition. In: Improved Crop Quality by Nutrient Management, Anac, D. and P. Martin - prevel (eds). Kluwer Academic Publishers. Pp: 19-22.

Ashraf, M.Y.; Gul, A.; Ashraf, M.; Hussain, F. and Ebert, G. (2010). Improvement in yield and quality of kinnow (citrus Deliciosa $\mathrm{x}$ citrus Nobilis) by potassium fertilization. Journal of Plant Nutrition Volume 33, 2010, Issue 11, p. 1625-1637.

Boman, B. (1997). Effectiveness of fall potassium sprays on enhancing grapefruit size. Proc. Flo. State Hort. Soc., 110: 1-7.

Calevert, D.V. and Smith, R.G. (1972). Correcting potassium deficiency of citrus with $\mathrm{KNO}_{3}$ sprays. Agric. and Food Chemist, 20 (3): 659661.
Davies, F.S. and Albrigo, L.G. (1994). Citrus. CAB International. Wallingford, UK.

Del-Caro, A.; Piga, A.; Vacca, V. and Agabbio, M. (2004). Changes of flavonoids, vitamin $\mathrm{C}$ and antioxidant capacity in minimally processed citrus segments and juices during storage. Food Chem. 84: 99-105.

Dhuique, M.C.; Veyrat, C.C.; Ollitrault, P.; Curk, F. and Amiot, M.J. (2005). Varietal and inter specific influence on micronutrient contents in citrus from the Mediterranean area. J. Agric. Food Chem., 53: 2140-2145.

El-Darier, S.M. (1991). Mineral composition in the eco-systems of fruit trees in Egypt, Citrus reticulate, Blanco and Citrus aurantium L. J. Islamic Academy of Sci., 4-3: 211220.

El-Tanany, M.M.; Abdel Messih, M.N. and Shama, M.A. (2011). Effect of foliar application with potassium, calcium and magnesium on yield. Fruit Quality and Mineral Composition of Washington Navel Orange Trees. Alexandria Science Exchange Journal, Vol. 32, No.1.

Embleton, T.W.; Jones, W.W.; Page, A.L. and Platt, R.G. (1969). Potassium and California citrus. Proc. $1^{\text {st }}$ Int. Citrus Symposium, 3: 15991603

Erner, Y.; Kaplan, B.; Artzi, B. and Hamu, M. (1993). Increasing citrus fruit size using auxins and potassium. Acta Hort., 329: 112-116.

Hand, S.B.; Nuray, K. and Feryal, K. (2005). Degradation of vitamin C in citrus juice concentrates during storage. Journal of Food Engineering, 74: 211-216.

Hsiao, T.C. and Lauchli, A. (1986). Role of potassium in plant-water relations. V. 2, pp. 281-312. In: Advances in Plant Nutrition. (Eds. B. 
Tinker and A. Lauchli) Praeger Scientific, New York.

Jose, A.Q.; Junior, D.M. and Boaretto, R.M. (2011). Sources and rates of potassium for sweet orange production. Sci. Agric. (Piracicaba, Braz.), V. 68, N. 3, p. 369-375.

Muhammad, Y. and Manzoor, A. (2010). Nutrition management in citrus: effect of multinutrients folliar feeding on the yield of kinnow at different locations. Pak. j. bot., 42(3): 1863-1870, 2010.

Mostafa, E.A.M. and Saleh, M.M.S. (2006). Response of Balady mandarin trees to girdling and potassium sprays under sandy soil conditions. Res. J. Agric. and Biol. Sci., 2 (3): 137-141.

Mostafa, E.A.M.; Hassan, H.S.A. and El Sabag, A.S. (2005). Influence of spraying $\mathrm{GA}_{3}$ and $\mathrm{KNO}_{3}$ on yield, fruit quality and leaf mineral contents of Balady mandarin trees. Minufiya J. Agric. Res., 30 (1): 283-295.

Nijjar, G.S. (1985). Nutrition of fruit trees. Mrs. Usha Raj Kumar for Kalyanin Publishers, New Delhi, pp. 10-52.

Snedecor, G.W. and Cochran, W.G. (1989). Statistical Methods. Iowa State University Press, Ames, Iowa.

Wu, T.; Guan, Y. and Ye, J. (2007). Determination of flavonoids and ascorbic acid in grapefruit peel and juice by capillary electrophoresis with electrochemical detection. Food Chem. 100: 1573-1579. 
تأثير مستويات مختلفه من السماد البوتاسي علي المحصول وجوده الثمار لاشجار البرتقال البلاي

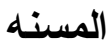

- تأثير مستويات مختلفة من السماد البوتاسي علي بعض الصفات الطبيعه للثمار و المحصول في البرتقال البلاي

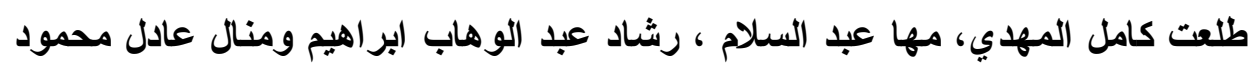

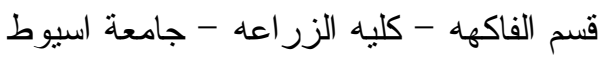

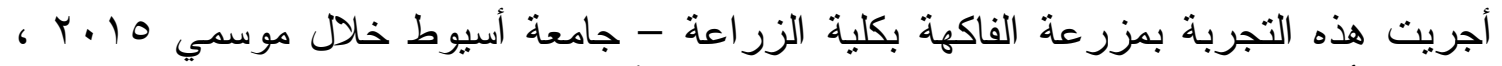

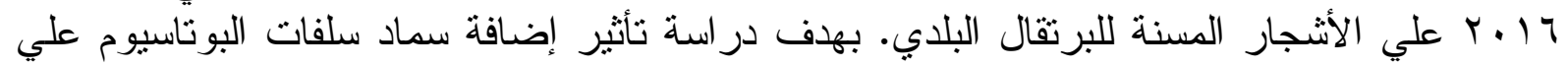

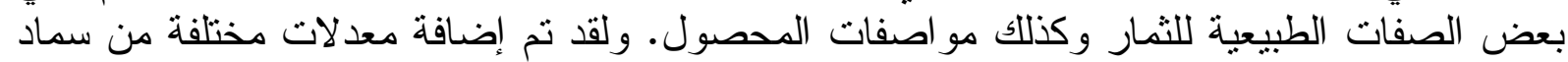

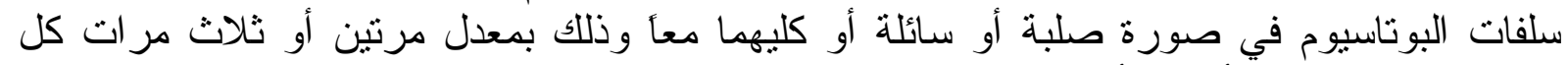
موسم إما رشأ علي ألأور اق أو إضافة ملافة للتربة.

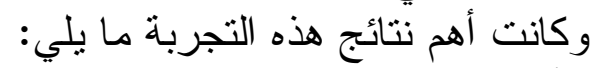

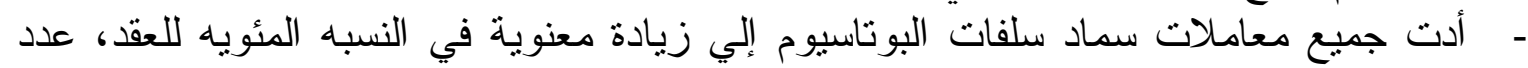

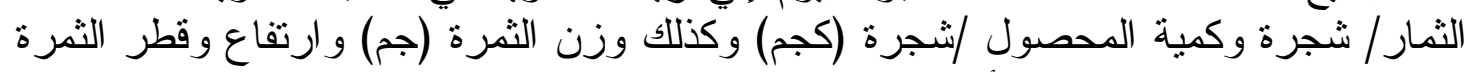

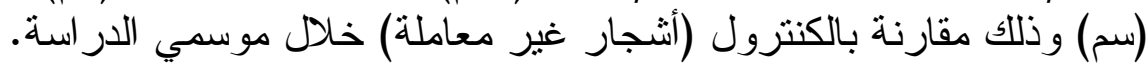

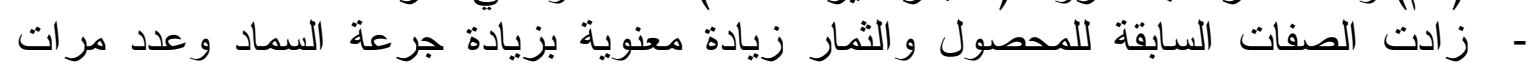

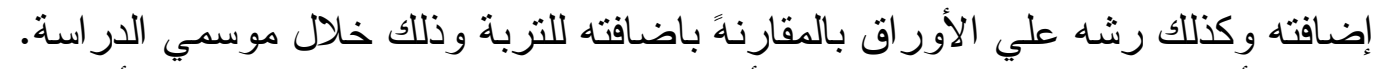

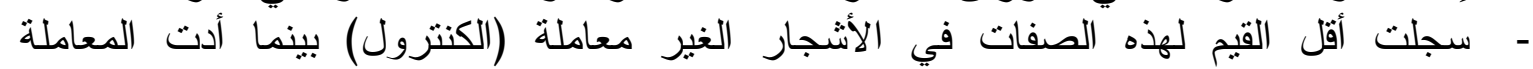

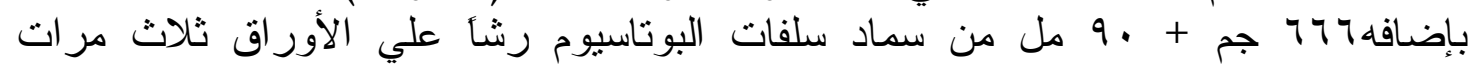
للحصول علي أعلي القيم لهذه الصفات خلادل موسمي الدر اسله. 